\title{
Toplumsal Cinsiyet Ayrımeılığının Yarattığı Engeller: Çalışma Yaşamında Varolmaya Çalışan Kadın
}

$\ddot{\mathbf{O} z}$

Geliş Tarihi (Received): 03.09.2021- Kabul Tarihi (Accepted): 13.12.2021

Tarihsel süreçte neredeyse tüm toplumlarda kadınlar ve erkekler ekonomik, toplumsal ve siyasal katılım açısından eşit fırsatlara sahip olamamıştır. Bu eşitsizliğin en önemli nedenlerinden biri kadın ve erkeğin toplumdaki rolü ile ilgili kalıpyargılar ve tutumlardır. Kadının modern anlamda çalışma yaşamına katılmasıyla kadına yüklenen roller çoğalarak kadınlar için yeni sorunları beraberinde getirmiştir. Çalışma yaşamına katılan kadın cinsiyetçi kalıpyargıların yarattığı dezavantajlı durumlarla yüzleşmek durumunda kalmıştır. Çalışmanın amacı da çalışma yaşamında kadınların toplumsal cinsiyet kalıpyargılarına bağlı olarak karşılaştıkları dezavantajlı durumları açıklamaya çalışmaktır. Örgütlerde bu dezavantajlı durumun yansıması olarak kabul edilen cam tavan, yapışkan zemin, cam asansör, cam uçurum, sızdıran boru, kraliçe arı sendromu, tokenizm, çifte açmaz, tiara sendromu, imposter sendromu, cam labirent, cam duvar kavramları literatür düzeyinde ele alınmıştır. Literatür taraması şeklinde planlanan çalışmada öncelikle feminizm, toplumsal cinsiyet ve kalıpyargılar hakkında bilgi verilmiş; daha sonra da kavramlar ayrıntılı olarak açıklanmıştır. Buna göre toplumsal cinsiyet kalıpyargıları ve ayrımcılık nedeniyle kadınların çalışma yaşamında dezavantajlı durumda olduğu, hak ettikleri pozisyona gelemedikleri ve aynı özelliklere sahip olsalar dahi erkeklerle eşit konumda olamadıkları ve çalışma yaşamında var olabilmek için yeni özellikler geliştirdikleri sonucuna ulaşılmıştır. Oluşan bu eşitsizliği önlemek ve kadınlar açısından gerçek bir eşitliğe ulaşmak için farkındalığı arttıran ve toplumsal cinsiyet eşitliğini sağlayan daha kapsamlı politika ve uygulamalar gerekir.

Anahtar kelimeler: toplumsal cinsiyet ayrımcıllğı,, cam tavan, cam uçurum, cam yürüyen merdiven JEL Kodu: J71

\section{Barriers Created by Gender Discrimination: Women Trying to Exist in Work Life}

\begin{abstract}
In the historical process, women and men in almost all societies have not had equal opportunities in terms of economic, social and political participation. One of the most important reasons for this inequality is stereotypes and attitudes about the role of women and men in society. With the participation of women in modern working life, the roles assigned to women have increased and brought new problems for women. Women who participated in the working life had to face the disadvantageous situations created by the gender stereotypes. The aim of the study is to try to explain the disadvantageous situations women face due to gender stereotypes. The concepts of glass ceiling, sticky floor, glass escalator/elevator, glass cliff, leaky pipe, queen bee syndrome, tokenism, double bind, tiara syndrome, imposter syndrome, glass labyrinth, glass wall, which are accepted as a reflection of this disadvantageous situation in organizations, are discussed at the level of literature. In the study planned as a literature review, first of all, information was given about feminism, gender and stereotypes; then the concepts are explained in detail. Accordingly, it was concluded that, due to gender stereotypes and discrimination, women are at a disadvantage in working life, cannot reach the position they deserve, and even if they have the same characteristics, they cannot be in an equal position with men and develop new characteristics to exist in working life. More comprehensive policies and practices that raise awareness and ensure gender equality are required to prevent this inequality and achieve real equality for women.
\end{abstract}

Keywords: gender discrimination, glass ceiling, glass cliff, glass escalator/elevator JEL Code: J71

\footnotetext{
${ }^{1}$ Dr. Öğr. Üyesi, Mersin Üniversitesi, Çalışma Ekonomisi ve Endüstri İlişkileri Bölümü, irepbayat@mersin.edu.tr

${ }^{2}$ Dr. Öğr. Üyesi, Kocaeli Üniversitesi, Çalışma Ekonomisi ve Endüstri İlişkileri Bölümü, beril.baykal@kocaeli.edut.tr
} 


\section{Giriş}

Tarihsel süreç içerisinde kadınlar, her dönemin şartlarına ve özelliklerine göre farklılaşan şekillerde çeşitli ekonomik faaliyetlere katılmıştır. Ancak kadınların çalışma yaşamına gerçek anlamda katılarak ücretli işçi statüsüne sahip olması ilk kez sanayi devrimi ile birlikte gerçekleşmiştir. Bu durumun en önemli nedeni Sanayi devriminin düşük ücretle çalıştırabileceği işgücü ihtiyacıdır. Kadınlar ilk defa Sanayi Devrimi ile birlikte bir ücret karşıllğı emeğini satmaya başlamıştır. Bu zamana kadar ev işleri ile ilgilenen, annelik yapan, ücretsiz aile işçisi olarak tarım sektöründe çalışan kadınlar; sanayi ve hizmetler sektöründe yer almaya başlamış; ancak niteliksiz işgücü olarak görülmeleri sebebiyle erkek işgücünün ikamesi olarak görülmüş ve düşük ücretli işlerde çalışmak durumunda kalmıştır (Durmaz, 2016).

Günümüzde küreselleşme süreci ile birlikte tüm dünyada kadınların çalışma yaşamına katılımı artmaktadır. Her ne kadar modern toplumun en önemli hedeflerinden biri, gelişmiş sosyal, kültürel ve ekonomik dönüşümü güvence altına alarak tüm toplum üyelerinin eşitliğini garanti etmek olsa da, kadınların ve erkeklerin işgücü piyasasına katılımla ilgili imkanları farklıdır. Tarihsel deneyim, ne ekonomik refahın ne de ileri siyasi kararların, kadınlar ve erkekler için eşit imkanları sağlamadığını ortaya koymaktadır. Bu eşit imkanlar konusunda en büyük engel, insanların erkek ve kadının toplumdaki rolü ile ilgili kalıpyargıları ve tutumları olarak ifade edilen toplumsal cinsiyettir (Akt. Kiaušienė ve Streimikiene, 2011). Dökmen'e göre (2010), toplumsal cinsiyet; toplumun kadın ve erkeği nasıl gördü̆ğü, nasıl algıladığı, nasıl düşündüğü ve nasıl davranmasını beklediği ile ilgili değerler, beklentiler, yargılar ve rollerle ilgilidir. Toplumsal cinsiyet, toplumsal cinsiyet rolleri ve toplumsal cinsiyet kalıpyargıları ile açıklanır. Toplumsal cinsiyet rolü kadın ve erkek için uygun görülen kişilik özellikleri, davranışlar ve roller, toplumsal cinsiyet kalıpyargıları kadınların ve erkeklerin göstermeleri beklenen özelliklerdir.

$\mathrm{Bu}$ çerçeveden bakıldığında geleneksel olarak kadının rolü ev işleri, annelik şeklinde görülürken; erkeklerin rolü çalışmak, para kazanmak vb rollerdir. Bilimsel literatürde de, bir kadının toplumdaki yerinin hala özel yaşamla "ev ve aile ile" ilişkili olduğu ve kamu alanının ve profesyonel yaşamın erkeklere ait olduğu yaklaşımı baskın şekilde vurgulanmaktadır (Akt. Kiaušienė ve Streimikiene, 2011). Ancak kadının çalışma yaşamına katılmasıyla birlikte kadına yüklenen roller çoğalmış ve toplumdaki yeri değişmeye başlamıştır.

Çalı̧̧ma yaşamına katılmasıyla birlikte kadın iki rekabetçi durumla karşılaşır: işyerindeki doğal rekabet ve toplumsal cinsiyete dayalı rekabet. Her ne kadar bu durum rekabet olgusu ile açıklanmaya çalışılsa da; aslında toplumsal cinsiyete dayalı ayrımcılık kapsamında değerlendirilmelidir. Çalışma yaşamında toplumsal cinsiyete dayalı ayrımcılık cam tavan, yapışkan zemin, sızdıran boru, cam asansör, cam uçurum, kraliçe arı gibi kavramlarla açıklanabilir. Kadınlar çalışma yaşamında bu mecazi kavramlar içinde sıkışmakta; cam tavanları aşıp üst sınırlara erişememekte, örgütlerin tabanına yapışık kalmakta, kariyerleri süresince rol yükleri, fırsat eşitsizlikleri gibi nedenlerle iş yaşamından çıkmak zorunda kalmakta, kadın mesleği olarak görülen alanlarda bile erkeklerin tercih edildiği ve öncelikli olarak terfi ettirildiği durumlarla karşılaşmakta ya 
da kadın yöneticiler tarafından mobbinge maruz kalmaktadır. Bu makalenin amacı da kadının çalışma yaşamında ve kariyer ilerleme basamaklarında yaşadığı bu cinsiyetçi ayrımcılığı kavramsal çerçevede açıklamaya çalışmaktır. Bu amaçla öncelikle feminizm ve toplumsal cinsiyet kavramları ele alınacak; daha sonra örgütlerde toplumsal cinsiyet kalıpyargılarının yansıması olarak görülen cam tavan, yapışkan zemin, cam asansör, cam uçurum, sızdıran boru, kraliçe arı sendromu, cam labirent gibi metaforlar literatür düzeyinde ele alınacaktır.

\section{Feminizm Kavramı, Toplumsal Cinsiyet ve Ataerkillik}

Aydınlanma döneminden itibaren kadınlar sosyal, siyasal, ekonomik ve hukuki alanda karşı karşıya kaldıkları eşitsiz muamelelere karşı mücadeleye başlamışlardır. Eşit haklar ve özgürlük talebi feminizm kavramının doğuşuna öncülük etmiştir. Feminizm kavramı ilk kez, Mary Wollstonecraft'ın 1792 yılında yayınladığ “ "A Vindication of theRights of Women” eseriyle de akademide yer almıştır (Akt. Taş, 2016).

Feminizm yaklaşımı, kadın ve erkeğin ekonomik, siyasal, sosyo-kültürel ve toplumsal hayatta eşitliğini savunur. Feminist hareketlerin tarihsel süreçlerini incelediğimizde farklı anlayış ve ideolojilerden etkilenerek hareketlerin şekillendiği söylenebilir. Birinci feminist dalgada, temel haklar olarak nitelendirilen kadınların oy kullanması, yönetimde yer alması, eğitimde fırsat eşitliği ve kadınların mülkiyet hakları talep edilmiştir. Ayrıca kadınların ev yaşamı eleştirilirken; ev işleri dışında da hareket özgürlügüne sahip olması savunulmuştur (Taş, 2016). İkinci feminist dalgada biyolojik cinsiyet ile toplumsal cinsiyet arasındaki ayrımın altı çizilmiş ve cinsiyete dayalı işbölümü eleştirilmiştir. Bu dalgada doğuştan getirilen ve cinslerin farklı biyolojik özelliklerini vurgulayan cinsiyet kavramının aksine toplumsal cinsiyet; kadın ve erkeğe farklı rol ve sorumluluk yüklemekte ve dolayısıyla toplumsal cinsiyete dayalı iş bölümünü doğurmaktadır. Bu işbölümü etrafında kadın ev merkezli, anne ve eş rollerini üstlenirken, erkek hane halkı reisi/aile reisi rolünü üstlenmektedir (Yıldız vd., 2016, s. 1125). Bu dalganın önde gelen ismi Simone De Beauvoir 1949 yılında yayınlanan kadın ve erkek eşitsizliğini ele alan "İkinci Cinsiyet” kitabında yer alan "Kadın doğulmaz, kadın olunur" sözü ile toplumsal cinsiyete vurgu yapmaktadır (Beauvoir, 2019).

Üçüncü dalga feminizm toplumsal cinsiyet tartışmalarının boyutlarının genişlediği dönem olmuştur. 1980'lerle birlikte kadınlarla erkeklerin farklılıkları üzerinde yoğunlaşan feminist ilgi, ikinci dalga feminizmi sadece beyaz, üst, orta sınıf kadınları dikkate aldığı için eleştirmiş ve kadınların kendi aralarındaki farklılıklara yönelmiştir (Bora, 2018, s. 41).

Kadın hakları konusunda gelişmeler ve ilerlemeler ne yönde olursa olsun tarihsel süreç kadınlar ve erkekler için eşit imkanlar olmadığını ortaya koymaktadır. Bu durumun nedeni erkek ve kadının toplumdaki rolü ile ilgili kalıpyargılar ve tutumları olarak ifade edilen toplumsal cinsiyettir. İnsanlar kültürel klişeler, batıl inançlar ve doğallaştırılmış tutumlar dünyasında yaşarlar. Tereškinas'ın (2004) bakış açısına göre, özellikle kadınlar ve erkeklerle ilgili, aile ve toplumdaki rollerine, diğer bir ifade ile toplumsal cinsiyet rollerine dair çok yönlü kalıpyargılar vardır ve çocukluğundan beri insanlar bu çok yönlü kalıpyargılarla yetiştirilir ve 
eğitilirler. Toplumsal cinsiyet kalıpyargıları, geleneksel olarak 'erkek' veya 'kadın' rolleri ve işlevleri olarak kabul edilen kültürel ve sosyal tutumlardır. Valackienė ve Krašenkienè'ye (2007) göre toplumsal cinsiyet kalıpyargıları, kadınların ve erkeklerin toplumdaki işlevleri ve sosyal görevleri ile ilgili iç tutumlardır. Örneğin; kadının aile içindeki görevi, erkeğin aileyi desteklemesi, kadının çocuklara bakması ve onları eğitmesi, erkeklerin güçlü olmaları sebebiyle ağlamamaları, erkeğin savunmacı, cesur korkusuz savaşçı olması ve kadının pasif ve korku dolu olarak bir erkeğe bağımlı olması gibi (Kiaušienė ve Streimikiene, 2011).

Toplumsal cinsiyet rollerinin ve kalıpyargıların yüzyıllardır ataerkil sistem içinde belirlendiği söylenebilir. Türkçe'de kelime anlamı erkek iktidarı olan ataerkillik kavramı, erkek otoritesine dayanan bir tür toplumsal örgütlenme düzenidir. Erkek egemen ataerkil sistem hem kamusal alanda, hem de özel alanda karşımıza çıkar. Erkeklerin baskı uygulayıp egemen olduğu ve kadınları denetim altında tuttuğu sistem, kadını ev ve aile alanı ile sınırlandırırken, erkeği kamu alanı olarak görülen siyaset, iş, vatan koruması, kültürel hayat gibi alanlarda hakim kılmakta; dolayısıyla kadınların evde ve sosyal yaşamda ikincil konumuna neden olmaktadır. Ataerkil sistemin sonucu olarak toplumsallaşma sürecinde kadının maruz kaldığı baskı ve ayrımcılık mekanizmaları cinsiyetçi kalıpyargılar üretmeyi sürdürmektedir (Akt. Korkmaz ve Başer, 2019; Özçatal, 2011). Bu cinsiyetçi kalıpyargıların da hem toplumsal yaşama hem çalışma yaşamına kadınların aleyhine olarak yansıdığı görülmektedir.

\section{Toplumsal Cinsiyet Ayrımcılığının Yarattığı Engeller}

Cinsiyetçi kalıpyargıları cam tavan, yapışkan zemin, sızdıran boru, cam asansör/cam yürüyen merdiven, cam uçurum, kraliçe arı, tokenizm, çifte açmaz, cam duvar, cam labirent, tiara ve imposter sendromu gibi sorunlarla çalışma yaşamına sirayet etmektedir.

\subsection{Cam Tavan Ve Yapışkan Zemin}

\section{Cam Tavan}

İlk defa 1985 yılında E. Gay Bryant'1n “The Working Woman Report: Succeeding in Business in the 80 's" kitabında kullanılan, bir yıl geçtikten sonra Carol Hymowitz ve Timothy Schellhardt'in, Wall Street Journal Report'da yayınlanan bir makalesinde kullanılarak popüler hale gelen cam tavan kavramı; Avrupa Komisyonu, OECD gibi uluslararası kuruluşlar tarafından da tanınarak literatüre girmiştir. Genel olarak kadınların üst yönetim hiyerarşisinde daha az temsil edildiğine vurgu yapan kavramda "tavan" kelimesi kadınların kariyer basamaklarını tırmanırken karşılaştığı bariyerleri/sınııı gösterirken, “cam” kelimesi bu sınır ya da bariyerlerin göreli görünmezliğini ve inceliğini ifade etmektedir (Casini, 2016; Sobczak, 2018, s. 53).

Kavramın akademik camiada benimsenmesi Morrison, White ve Velsor'un (1987) “Breaking The Glass Ceiling: Can Women Reach The Top Of America's Largest Corporations?” kitabı ile olmuştur. Yazarlar cam tavanı "örgütlerde kadınların üst yönetim kademelerine yükselmesini engelleyen bir bariyer olarak tanımlarken (Akt. Sabharwal, 2013, s. 400); Avrupa Komisyonu "erkeklerin egemen olduğu örgütlerde, kadınların üst düzey pozisyonlara erişmesini önleyen karmaşık yapılardan kaynaklanan görünmez bariyer" 
(European Commission, 1998, s. 33) olarak tanımlar. Kavram, kadınların üst düzey yöneticiliği önünde engel oluşturan, tutumsal ve örgütsel önyargılar tarafından meydana gelen görünmez yapay engelleri ifade eder (Wirth, 2001, s. 1).

Tanımlardan anlaşılacağı üzere kadınların yükselmeleri önündeki engellerin görünmezliği ile ilgili olan "cam” metaforu, mesleki başarı önündeki eğitim düzeyi düşüklüğü, mesleki deneyim yetersizliği gibi fiziksel ve formel engellerle ilgili olmayıp; toplumsal cinsiyet kalıpyargıları sonucu oluşan tutumsal bir engeldir. Kısaca cam tavan, çalışma yaşamında toplumsal cinsiyet ayrımcılı̆̆ının bir yansıması olarak ifade edilir. Kavram çalışma yaşamındaki ayrımcılığı yansıtırken sadece kadınların örgüt içinde hiyerarşik olarak yükselmelerini ele almaz; ücretlendirme, eğitim ve geliştirme, iletişim gibi örgüt uygulamalardan yararlanmadaki eşitsiz uygulamaları da kapsar (Sökmen ve Şahingöz, 2017).

Dreher (2003, s. 543) cam tavanı açıklayan teorileri "arz taraflı teoriler" ve "talep taraflı teoriler" olmak üzere iki grupta toplar. Kadınlar ve erkekler arasındaki bazı nitelik farklılıklarının kadınların yönetimin üst kademelerine yükselmelerini engellediğini ileri süren arz taraflı teorilerin açıklamalarının bir kısmı beşeri sermaye teorisine dayanır. Beşeri sermaye teorisine göre, kadınların eğitim ve kariyer açısından erkeklerden daha az beşeri sermayeye sahip olması, yönetimin üst kademelerine yükselmelerini engelleyen bir cam tavan oluşturur. Arz taraflı açıklamaların bir diğeri rollerin sosyalizasyonu teorisine dayanır. Buna göre erken dönemde başlayan cinsiyet rolleri sosyalizasyonu, avantaj sağlayan yöneticilik kariyerlerinin erkekler tarafından benimsenmesine ve erkekler tarafından yürütülmesinin uygun olacağı anlayışına sebep olmaktadır (Dreher, 2003, s. 543). Burada en belirgin önyargı kadının annelik ve hane içi rolleri ile ilgilidir. Kadınlar aile ve hane içi sorumlulukları nedeniyle "yüksek riskli çalışanlar" olarak değerlendirilmekte ve bu nedenle yönetsel pozisyonlar için uygun aday olarak düşünülmemektedir (Sobzcak, 2018, s. 53). Burada sosyal rol teorisinden de bahsetmek mümkündür. Teoriye göre erkeklerin gösterdiği bazı toplumsal davranışlar saldırganlık, atılganlık, liderlik, kendine güven, müzakerelerde güçlü olma, baskınlık ve hırs iken; kadınlara atfedilen toplumsal davranışlar nezaket, kibarlık, sevecenlik, empati kurma, besleyici olma, duyarlılık ve yardımseverliktir. Bu farklılıklar sosyal rol teorisinin temelini oluştursa da Eagly ve Karau (2002), liderlik rollerinde kadınlara karşı önyargılar olduğunu belirterek kadınların liderlik rollerinde dezavantajlı olarak kabul edildiğini belirtmiştir (Akt. Sabharwal, 2013, s. 401). Arz taraflı yaklaşımların sonuncusuna göre kadınlar genellikle kendinden yaş olarak büyük ve çalışma yaşamında daha çok deneyime sahip olan eşleri seçme eğilimde olup; daha yüksek gelire sahip olan eşin kariyerinde ilerlemesini teşvik etme eğilimindedir (Dreher, 2003).

Talep taraflı teoriler sosyal iletişim teorisi (Blau ve Kanter, 1977) ve stratejik insan kaynakları yönetimi yaklaşımıdır. Kanter, azınlık grubu üyelerinin, çoğunluk üyeleri tarafından sergilenen bir dizi sosyal davranış nedeniyle dezavantajlı konumda olduğunu ileri sürer. Örneğin, çoğunluk olan üyeler, kendileri ile azınlık olan üyeler arasındaki farkları olduğundan daha büyük göstererek, azınlıklara karşı kalıpyargılar 
geliştirebilirler. Bu durum, azınlık durumunda olan üyelerde sosyal izolasyon, performans ve rol beklentilerine uyma baskısı yaratarak, onları cam tavan ile karşı karşıya getirir. Sosyal iletişim teorisi cam tavan olgusu açısından düşünüldüğünde teori, daha fazla kadın, erkek egemen hiyerarşilere girmeyi seçtiğinde, zaman içinde kadınların fırsatlarını arttıracağını öngörmektedir. Diğer bir deyişle, genel örgütsel değerler kadınların yönetici pozisyonlarına yükselmesi ile ilgili olarak olumlu yönde değişime uğradıkça, daha fazla kadın alt düzey yönetim kariyer yollarını izleyecektir. Alt düzey yönetici pozisyonlarındaki kadınların oranı arttıkça, kadınlar daha az izolasyon ve sosyal baskı yaşayacak, koalisyonlar ve destek ağları kurmaya başlayacak ve üst düzey pozisyonlar için aday olarak daha kabul edilebilir hale gelecektir. Stratejik insan kaynakları yönetimi yaklaşımı örgütlerin kadınlar için kariyer fırsatları sağlama konusunda daha aktif ve agresif bir tutum takınmaları halinde yönetim yeteneğine sahip nitelikli kadın işgücü havuzundan daha etkin bir şekilde yararlanabileceklerini öngörür (Dreher, 2003, ss. 543-545).

Olgunun belirgin bir şekilde cinsiyet temelli olduğunu vurgulayan Cotter vd. (2001) göre cam tavan olgusun dört belirgin özelliği bulunur:

- Çalışanın iş ile ilgili diğer özellikleri ile açıklanamayan cinsiyet eşitsizliği,

- Performans artışı gözlemlense dahi yüksek düzeyde cinsiyet eşitsizliği ya da ırksal eşitsizlik,

- Daha yüksek pozisyonlara ilerleme firsatında cinsiyet eşitsizliği,

- Kariyer boyunca artan cinsiyet eşitsizliği.

Anlatılanlar ışığında kadınların kariyeri önündeki görünmez engeller, diğer bir ifade ile örgütlerde cam tavana neden olan faktörler şu şekilde sıralanabilir (Sabharwal, 2013, s. 401; Y1ldız vd., 2016, s. 1128; Casini, 2016):

- Bireysel faktörler: kişilik özellikleri, toplumsal cinsiyetçi rol modelleri, öğrenilmiş çaresizlik, kraliçe arı sendromu, üstlenilen çoklu roller, kişisel tercih, beşeri sermaye bariyerleri/engelleri (eğitim, finans, kaynak ve deneyim eksikliği)

- Örgütsel faktörler: firsat eşitliğini sağlamayan örgüt politikası, örgüt kültürü ve iklimi, örgütsel iletişim yapısı, mesleki cinsiyet ayrımcılı̆̆ı, örgütsel önyargılar, sınırlı iş-yaşam programları

- Toplumsal faktörler: ataerkil toplum yapısı, toplumsal cinsiyet ayrımcılı̆̆ı, cinsiyet temelli kalıpyargılar

Özetle; “cam tavan” kadınların daha yüksek pozisyonlara ulaşması önünde engeller oluşturmakta ve kadınların profesyonel kariyerinin gelişimini ve ilerlemesini büyük ölçüde etkilemektedir (Kiaušienè ve Streimikiene, 2011).

\section{Yapışkan Zemin}

Birçok ülkede kadınlar erkeklerden daha çok işsizlik sorunu ile karşı karşıya kalmakta olup bu durum kadınların istihdama katılma oranları da etkilemektedir. İstihdama katılsa dahi kadınlar görece daha düşük seviyede işlerde, yarı zamanlı ya da geçici olarak ve daha düşük ücretlerle çalışmaktadır. Bu durum bir diğer negatif olgu olan yapışkan zemin (sticky floor) kavramını işaret etmektedir. İş hiyerarşisinde daha düşük düzey 
işlerde az düzeyde ilerleme imkanı olan çalışmayı (OECD, 2016) ifade eden yapışkan zemin kavramı, işgücü piyasasındaki kadınlara yönelik ayrımcı uygulamalar için kullanılır (Sobczak, 2018, s. 53). Daha düşük ücretler ile çalışan, işlerinde mobilitesi düşük ve kariyerinde daha fazla ilerleyemeyen kadınları ifade eden kavram; kadınların ailevi yükümlülükler, kadına yönelik tutumlar ve kalıpyargılar ve hatta örgüt yapıları nedeniyle kariyerlerinde karşılaştıkları engelleri ifade eder (Akt: Pascall, 2012).

European Institute For Gender Equality’e (EIGE) göre yapışkan zemin; çalışanların özellikle kadınların, alt kademeli işlerde yer alması, hareket kabiliyetlerinin düşük olması ve kariyer gelişiminde önlerinde görünmez engellerin bulunmasına neden olan ayrımcı bir istihdam modeline işaret eden bir metafordur.

Randy Albelda ve Chris Tilly kavramı; kadınların kariyerlerinin alt basamaklarına sıkışıp kalmasına neden olan ayrımcı işe alma kalıpları olarak tanımlarken; Stijn Baert, Ann-Sophie De Pauw ve Nick Deschacht yapışkan zemini, kadınların, erkeklerle karşılaştırıldığında, kariyer basamaklarını tırmanmaya başlama olasılıklarının daha az olması olarak tanımlar (Akt: Sobczak, 2018, s. 52-53).

\subsection{Cam Uçurum}

Cam uçurum ( glass cliff) kavramı literatürde ilk kez, Exeter Üniversitesi, Sosyal Psikoloji bölümünden İngiliz profesörler S. Alexander Haslam ve Michelle K. Ryan tarafindan 2004 yılında "kurumsal dünyada, kadın yöneticilerin, kriz ya da sıkıntılı/ekonomik darboğaz durumlarında, ya da başarısızlık ihtimallerinin yüksek olduğu durumlarda, erkeklerden daha fazla liderlik konumuna getirilmelerini” tanımlamak için kullanılmıştır. Ryan ve Haslam 2003 yılında FTSE 100 şirketin hisse-fiyat performanslarını, kadın ve erkek yönetim kurulu üyeleri atanmadan önce ve sonra incelemişve kötü performans tecrübesi olan örgütlerde kadınların, yönetim kurullarına atanmış olduğu sonucuna ulaşmıştır (Haslam ve Ryan, 2008). Buradan yola çıkarak Ryan, Haslam ve Postmes (2007, s. 183) cam uçurum kavramını, göreceli olarak kadınların karşı karşıya kaldığı üstü kapalı/zımni bir bariyer ve güvencesiz durumlarda kadınlara liderlik/yöneticilik verilmesi ihtimalinin daha yüksek olması ile açıklar. Cam uçurum kavramı, cam tavanı aşan kadınların, örgütün kriz dönemlerinde, başarısız olma ihtimalinin yüksek olduğu üst düzey yöneticilik pozisyonuna getirilerek (cam uçurumdan itilerek), başarısızlıklarını cinsiyetleri ile ilişkilendirmek için kullanılmıştır (Yıldız vd., 2016, s. 1119). Özetle kavram başarısızlık riski olan ama kolayca görünmeyen tehlikeyi ifade eder; bir kere cam tavan kırılıp kadınlar liderlik pozisyonuna ulaşınca, kendilerini cam uçurumda bulma olasılıkları erkeklerden daha fazladır.

Bu kavram ile kadınlara genel mali gerileme ve şirket performansındaki gerileme koşullarında liderlik pozisyonu verilmesi durumu kastedilir. Bu şekilde, kadınlar bir cam uçurumun üzerine yerleştirilmiş sayılır ve güvencesiz bir liderlik pozisyonunda başarısız olma ihtimalleri artar. Bu kadınlar, erkek meslektaşları kadar performans gösterdiklerinde dahi erkeklerden daha fazla inceleme ve eleştiriye tabi tutulur. Örneğin iddialı bir erkek yönetici uygun/yerinde liderlik sergiliyor olarak görülürken, aynı şekilde davranan kadın yönetici kabul 
edilemez şekilde saldırgan olarak düşünülür. Daha istikrarsız olan bu belirli görevlerde başarısız olma, suçlama ve aşağılanma konusunda seçilme olasılıkları daha yüksektir (Ryan vd., 2011; Pascall, 2012).

$\mathrm{Bu}$ duruma yönelik açıklama sosyal psikologlar tarafindan yapılır. Sosyal psikologlar toplumda liderliğin çoğunlukla erkeklerle ilişkili bir yetenek olarak kabul edildiğini ifade eder. Etkili bir liderlik için literatürde belirtilen özelliklerin (risk alma, kararlılık, iddialı olma, hırs vb) çoğunluğu erkek özellikleridir.“Think Manager-Think Male” olgusu liderlik pozisyonunda erkeklerin rolünü daha fazla açıklamaktadır. Bu olgu yönetici seçimi, terfi ve eğitim kararlarında kadınlara karşı önyargı yaratan psikolojik bir bariyerdir (Schein vd., 1996, s. 34). İşyerinde birçok toplumsal cinsiyet eşitsizliğinin temelini oluşturan "Think Manager - Think Male" anlayışı düşük performans ya da kriz dönemlerinde yerini "Think Crisis Think Female" anlayışına bırakmış ve cam uçurum kavramının önünü açmıştır (Ryan vd., 2011).

Bu bağlamda örgütlerde cam uçuruma neden olabilecek faktörler örgütlerde cinsiyetçilik, kadınların destek ağlarının eksikliği, kadınlar ve liderlerle ilişkili kalıp yargılar, kriz yönetimi ile ilişkili kalıpyargılardır (Ryan vd., 2007, s. 185).

\subsection{Cam Yürüyen Merdiven / Cam Asansör}

Yönetim pozisyonunda toplumsal cinsiyet ayrımcılığı ile ilgili birçok çalışma erkek egemen ortamdaki kadın deneyimlerine odaklanır. Hem araştırmacılar hem de sosyal değişimin savunucuları, çabalarını kadınlar erkek egemen alana entegre olduklarında ve kadınların örgütsel basamakları tırmanırken karşılaştıkları zorlukları ortaya çıkarmaya yönlendirmiştir. Ancak Christine Williams (1995) araştırmacıların madalyonun diğer tarafına, kadın egemen ortamda erkeklerin durumuna dikkat etmesi gerektiğini vurgular (Akt. Macarie ve Moldovan, 2012, s. 167).

Erkek egemen ortamda, yönetim pozisyonuna gelmekte engellerle "cam tavanla" karşılaşan kadın çalışanların aksine, kadın egemen ortamdaki erkeklerin hiyerarşideki hızlı yükselişlerine, yüksek ücret almalarına ve otoriteye sahip olmalarını açıklayan metafor, cam asansör (glass elevator)/cam yürüyen merdivendir (glass escalator). Cam yürüyen merdiven kavramı, kadın mesleklerindeki erkeklerin konumlarını güçlendiren ince mekanizmalardır. Christine Williams (1995) 'cam yürüyen merdiven' etkisini, kadın hakimiyeti altındaki profesyonel mesleklere giren erkeklerin otorite pozisyonlarına ve daha yüksek ücretlere daha hızlı ilerlediği şeklinde ifade ederek, cam yürüyen merdiveni erkeklere örgüt içinde hızlı geçiş imkanı sunan ya da mancınıkla/sapanla yükseklere çıkaran uygulamalara benzetir (Akt. Wingfıeld, 2009, s. 7; Dill vd., 2016; Price-Glynn ve Rakovski, 2012). Williams, kadın egemen işlerde çalışan erkek tokenlerin, erkek egemen işlerde çalışırken kadın tokenleriyle aynı tür ayrımcılığa maruz kalmadığını; aslında erkeklerin işe alım sürecinde tercih edildiğini ve kadın egemen mesleklerdeki en erkeksi işleri sürdürmeye teşvik edildiğini ifade eder (Akt. Smith, 2012, s. 153). 
Kavram; kadınların egemen olduğu hemşirelik ve öğretmenlik gibi meslek alanlarında kadın meslektaşlarına nazaran daha az temsil edilen erkeklerin kariyer basamaklarını daha hızlı tırmandıklarını, yönetici pozisyonuna daha kolay terfi ettirildiklerini açıklamak için kullanılmaktadır (Pascall, 2012).

Kadın egemen ortamda çalışan erkeklere odaklanan birkaç araştırmacıdan biri olan Williams; 19851991 yılları arasında, ABD’nin 4 büyük şehrinde, kadın işi olarak görülen 4 farklı profesyonel meslekten (hemşire, ilkokul öğretmenleri, kütüphaneciler ve sosyal hizmet uzmanları) 99 kişi ile (76 erkek, 23 kadın) görüşmüştür (Williams, 1992, s. 253). Araştırma, kadın mesleği olarak adlandırılan işlerde sayısal azınlıkta olan erkeklerin terfi gibi konularda daha avantajlı olduğunu ve kadınlardan farklı olarak hemşirelik, ilkokul öğretmenliği ve sosyal hizmet gibi kadın egemen işlerde erkeklerin aynı karmaşık kariyer engelleri ile karşı karşıya olmadığını ortaya koymuştur. Araştırmaya göre erkekler bazı ayrımcılıklardan etkilenseler de bunlar şekil ve sonuçlar bakımından farklıdır. Örneğin erkeklerin karşılaştığı ayrımcılık genellikle mesleğin dışındaki bireylerin önyargılarından kaynaklanmaktadır. Bu erkekler başarısız insanlar ya da homoseksüeller olarak görülür. Ancak bu tür olumsuz tutumların kariyerleri üzerinde herhangi bir olumsuz etkisi yoktur (Williams, 1992, s. 253; Casini, 2016).

Williams'dan önceki araştırmalar kadın egemen mesleklerde erkeklerin, erkek egemen alandaki kadınlarla benzer problemleri yaşadığını öne sürerken, William'ın araştırması bu teoriyi çürütür ve yeni hipotezler ortaya koyar. Kadın egemen mesleklerdeki erkekler, daha düşük kariyer basamaklarından başlamalarına rağmen, cam yürüyen merdiven ile karşılaşarak (örgütteki üst düzey pozisyona yükselmek için bask1 ve firsatlarla karşılaşarak) idari ve yönetim bölümlerine daha fazla yönelir. Erkek egemen mesleklerdeki (informal olarak dışlanan ya da izole edilen) kadınların aksine, Williams'ın araştırmasındaki erkekler, yönetim pozisyonundaki erkek mentorlardan oluşan bir ağın desteğini alırlar. Erkekler tarafindan oluşturulan bu gayriresmi ağların, üyelerini yüksek prestij ve finansal ödül sağlayan üst pozisyona yükselteceği genellikle kabul edilir. Kadın egemen mesleklerde, erkeklere yönelik ayrımcılığın tek türü, dış çevreden gelen kalıpyargı ve önyargılardır. Bu nedenle Williams'ın çalışmasının sonucuna göre; tipik olarak feminen kabul edilen mesleklerdeki erkekler bir cam tavanla değil, daha ziyade profesyonel gelişimlerini ve terfilerini kolaylaştırıcı cam yürüyen merdiven ile karşılaşırlar (Akt. Macarie ve Moldovan, 2012, ss. 167-168).

Bu alanda yapılmış bir diğer önemli çalışma Hultin tarafından yapılmıştır. Hultin (2003) cam yürüyen merdiven hipotezi ile ilgili 1965-1991 yıllarını kapsayan İsveç Yaşam Düzeyi araştırmalarından elde ettiği bilgilerden (3119 bireyle; 1535 erkek, 1584 kadın) 3 farklı meslek türünde (erkek egemen meslekler, karma meslekler ve kadın egemen meslekler) boylamsal analiz yapmıştır. Cam yürüyen merdiven olgusunu doğrulayan araştırmaya göre; kadın egemen mesleklerde \%12,7 erkek ve sadece \%5.6 kadın terfi ettirilmiş; karma mesleklerde erkeklerin \%7.9'u, kadınların sadece \%2,5'i terfi alabilmiştir (Akt. Macarie ve Moldovan, 2012, ss. 167-168). 
Erkekleri bazı meslekleri düşünmekten bile alıkoyan ve bu işleri “kadın işi’” yapan erkeklere uygulanan sosyal ve kültürel yaptırımlardır. Bu kültürel engellerin açıkça görüldüğü alanlardan biri, medyanın erkek egemen mesleklerde hem erkek hem kadınlara yer verirken, hemşire, sekreter gibi kadın egemen mesleklerde erkeklere yer vermemesidir. Televizyon nadiren erkekleri geleneksel olmayan iş rollerinde tasvir eder ve bunu anomali gibi yansıtarak programın merkezi odak noktası ve şaka konusu haline getirir (Williams, 1992, s. 264).

Williams (2013) 21. Yüzyılda işgücü piyasası koşullarının değiştiğini belirterek cinsiyet ayrımcıllğına yönelik “Erkekleri üstün kılan nedir?, Erkeklerin kazançları nelerdir?” gibi yeni sorular sorulması gerektiğini belirtir. Aynı zamanda cam yürüyen merdiven kavramını açılarken; bunun her erkeğe uygulanmadığını, cinsel yönelim, ırk ve etnik azınlık temelinde erkeklerin cam yürüyen merdivenin imkanlarından faydalanamadığını ve dışlandığını belirtir.

\subsection{Kraliçe Arı Sendromu}

Arı kovanlarında kraliçe arının iktidarını devam ettirme arzusu gibi örgütsel yaşamda da kraliçe arı özelliği taşıyan kadınların varlığından yola çıkılarak "kraliçe arı sendromu" (queen bee syndrome)kavramı oluşturulmuştur (Er ve Adıgüzel, 2015, s. 164).

G. Staines, C. Tavris ve T.E. Jayaratne'in 1973'deki çalışmalarında bazı kadınların geleneksel cinsiyet rollerindeki değişikliğe karşı olduklarını görerek "üst yönetimdeki/kıdemli kadınların, örgütteki diğer kadınlara karşı kötü davranışlarını" ifade etmek amacıyla "kraliçe arı" kavramını kullanmıştır (Mavin, 2008, ss. 75,79). Özellikle erkek egemen sektörlerde lider rolünde olan ve diğer kadın 'işçi arıları' elde tutmak için pozisyonunu kullanan bir kadını tanımlamak için kullanılan kavram; bazıları için basit bir kendini koruma iken bazıları için, erkeklerin kadınlardan daha üstün olduğuna inanan bir toplumda, rüştünü ispatlamanın yansımasıdır. Bu bağlamda, kraliçe arı davranışı sadece cinsiyet ayrımcılığının nedeni değil aynı zamanda bu ayrımcıllğın bir sonucudur (Sandberg 2013; Vachon, 2014, s. 289)

Kraliçe arı fenomeni üzerine yapılan araştırmalar, kraliçe arıların erkek gibi olmak, diğer kadınlardan farklı olduklarını vurgulamak ve mevcut cinsiyet hiyerarşisini onaylamak ve meşrulaştırmak olmak üzere üç ana davranış kalıbı olduğunu savunur (Derks, 2017, ss. 1297-1298). Yine araştırmalara göre kraliçe arıların cinsiyetçi tutumları içselleştirerek kadınlara karşı kullanma, örgütte olan kadınların rekabet edebilirliğini ortadan kaldırmaya çalışmak ve ayrımcılıkla ilgili yapılanları görmezden gelmek vb. davranışları bulunmaktadır (Zel, 2002, s. 39). Bu davranışları ile kraliçe arılar örgütte çalışan diğer kadınların yaşamlarını zorlaştıırken, özellikle başarılı ve yetenekli kadın adayların örgüte katılımını ve örgütte ilerlemesini engellemeye çalışır (Akt. Durmaz, 2016).

Kraliçe arılar olumsuz özellikleri ve davranışları olan kadınlar olarak gösterilse de; Hollanda Leiden Üniversitesi'nden profesör Belle Derks'in araştırmasına göre, kadınların diğer kadınlara kötü davranmasının nedeni kadın yöneticiler değil; çoğunluğunu erkeklerin oluşturduğu cinsiyetçi çalışma ortamının doğal bir sonucudur; dolayısıyla kadın yöneticiler bu erkek egemen çalışma ortamında var olabilmek amacıyla bu tip 
davranışlarda bulunmaktadır. Aynı şekilde Kraliçe Arı Sendromunun bir önyargıdan ibaret olduğunu gösteren 'Kraliçe Arı Sendromu'nu cinsiyet ayrımcılı̆̆ına dayalı bir önyargı olarak gören Bickford'a (2011) göre, kadınlara gerekli eğitim verildiği ve kadınlar düzgün rol modellerle desteklendiği takdirde kadınlar kariyerlerinde daha sağlam adımlarla üst kademelere ilerleyebilir (Akt. Er ve Adıgüzel, 2015). Derks ve diğerleri (2016, s. 457) de, erkek egemen örgütlerde bireysel başarıya ulaşan kadınları erkeksi kültüre uydurarak ve onları diğer kadınlardan uzaklaştırarak bu kadınlara aşağılayıcı şekilde "bir kraliçe arı etiketi" verildiği sonucuna varmıştır.

Kraliçe Arı Sendromu, hem kraliçe arılar olarak görülebilen kadınlar ve astları için hem de kadınların bir grup olarak sosyal konumu için belirli sonuçlara yol açmaktadır. Kraliçe arı gibi davranan kadın, erkeklerin egemen olduğu örgütlerde başarılı olsa da astları olan genç kadınlar tarafından etkili bir lider olması konusunda desteklenmemektedir (Derks, 2017, s. 1299). Astları ile ilgili cinsiyet kalıpyargılarını koruyan kraliçe arılar, diğer kadınların kariyerleri üzerinde önemli bir etkiye sahip olabilir. Kraliçe arı davranışları genç kadınların özgüvenini yok edebilir ve bu nedenle başarı şanslarını olumsuz yönde etkileyebilir (Derks vd., 2016, s. 457). Son olarak, Kraliçe Arı Sendromu, işyerinde cinsiyet ayrımcıllı̆ının sürdürülmesine yol açar. Kraliçe arıların örgütlerde kadın ve erkek arasındaki mevcut eşitsizlikleri reddetmeleri ve toplumsal cinsiyet kalıpyargılarını devam ettirmeleri ayrımcılığın meşrulaştırılmasına yol açmaktadır (Derks, 2017, s. 1299; Derks vd.,2011, s. $520)$.

\subsection{Sizdıran Boru}

Sızdıran boru (leaky pipeline) kavramı, özellikle bilim ve akademi alanında kadınların hem eğitim hem de kariyerlerinin önemli aşamalarında neden ayrıldıklarını veya ilerleyemediklerini açıklamaya çalışır. Her ne kadar eğitim ve istihdamda kadınların oranı artıyor olsa da; hala erkekler ile karşılaştırıldığında önemli bir farklı11k görülmektedir.

Sue Berryman "Who Will Do Science? Minority and Female Attainment Of Science And Mathematics Degrees" (1983) isimli raporunda, kadınların nicel disiplinlerde lisans, yüksek lisans ve doktora derecelerinde temsilini özetlemeye yardımcı olmak için kavramsal metafor olarak bir boru kavramını kullanarak, bilim insanı olma sürecinde eğitim ve istihdamın tüm aşamalarında ortaya çıkan cinsiyet farkının ampirik analizinde büyük bir yenilik olarak görülen bir model ortaya koymuştur. Model, kadınların eğitim ve çalışma yaşamlarında nerede ayrıldığını, nerede azalmaya başladığını ve nerede kadın işgücü arzında kıtlık olduğunu açıklamaya çalışır ve bu durumu sızdıran bir boruya benzetir (Akt. Rajenderan ve Zawawi, 2019, s. 1161).

Bennett'in boru modeli, kadınların eğitimden istihdama geçişi, kariyer yolu ya da bilimsel uzmanlık seçimleri ve daha yüksek ücret ve itibar sağlayan daha üst düzey seviyelere ilerlemenin hızı ve zorluğunun bir analizini ön plana çıkarır. Bu şekilde, model iki geniş araştırma problemi barındırır. Birincisi, kadınların çoğunun neden kariyer ilerlemesinden vazgeçtiğini veya boru hattından 'sızdığını' açıklamayı amaçlayan 
bireysel seçimlerini araştırırken; ikincisi, bu durağan kariyerleri ve erken ayrılmaları örgüt ve bilim kuruluşları açısından performans, beklentiler ve toplumsal cinsiyet ilişkileri bağlamında inceler (Bennett, 2011).

Kadınların hedeflerini ve potansiyellerini yerine getirmeden neden kariyerlerinden vazgeçtiklerinin önemli bir açıklaması, anne olduklarında ev ve aile sorumluluklarına daha fazla önem vermelerdir. İşgücü piyasası ayrımını bir bütün olarak inceleyen Catherine Hakim (1996), kadınların kariyerlerinde başarı düzeylerinin düşük olmasının kaynağını ve kadınların ve erkeklerin ekonomik sonuçları arasındaki farklılıkları açıklayan unsurun kendi istihdamları ve yaşam tarzları hakkında kendi seçimleri olduğunu iddia eden Tercih Teorisini ortaya koymuştur. Teori kadınları, ücretli istihdama verdikleri önceliklere göre istihdama öncelik veren iş merkezli kadınlar, iş ve aileyi birleştirmek isteyen ve dolayısıyla kariyer odaklı olmayan ya da planlanmamış kariyere sahip olan kadınlar ve son olarak aileyi merkeze alan ve tek meşguliyet alanı olarak gören ev merkezli kadınlar şeklinde gruplandırır (Akt. Bennett, 2011, s. 156).

\subsection{Tokenizm/Sembolleştirme}

Her geçen gün çalışma yaşamında kendine daha fazla yer bulan kadınlar, cinsiyetçi tutumların yarattığı olumsuzluk ve sorunlarla baş etmek durumunda kalmaktadır. "Tokenizm" erkek egemen örgütlerin ayrımc1 uygulamalarını gizleyebilmek ve vicdani yükümlülüklerini hafifletmek için azınlık grupta yer alanlara sembolik olarak yer vermesidir.

Literatürde kavramı ilk popüler hale getiren kişi Judith Long Laws (1975) olsa da; Everett Hudges (1945) “dışlanmış", Georg Simmel (1950) “yabancı" kavramlarını benzer durumu ifade etmek için kullanmıştır. 1975 yılında Laws erkek egemen akademik ortama giren kadınların karşılaştığı sorunları anlatmak amacıyla "token" kavramını kullanırken; Hudges ve Simmel bir gruba giriş için tüm resmi gereklilikleri karşılayan, ancak o pozisyondaki kişilerden beklenen diğer özelliklere (özellikle 1rk, cinsiyet ve etnik köken) sahip olmayanları tanımlamak için "dışlanmış” ve "yabancı" kavramlarını kullanmıştır (Akt. Zimmer, 1988, s. 65). Token kavramının yaygın olarak kullanılması Rosabeth Moss Kanter'in (1977) “Men and Women of The Corporation" adlı çalışmasında örgütlerde yeterince temsil edilmeyen kadınların deneyimlerini incelediği kitabıyla olmuştur (Kumkale, 2019, s. 3). Kanter'e göre tokenizm bir grubun diğer grup üzerinde 85 'e 15 oranında üstünlük kurması durumunda ortaya çıkmaktadır ve çoğu yönetim pozisyonunda bu üstünlük nedeniyle erkekler "baskın” kadınlar “token” konumundadır (Zimmer, 1988, ss. 6566).

Dolayısıyla asker, polis, mühendis, pilot gibi mesleklerde cinsiyetçi kalıpyargılar sonucu sembolik olarak az sayıda kadının istihdam edilmesiyle ve şirket yönetim kurulu ve siyasi parti gibi örgütlenmelerde az sayıda kadına yer verilerek ayrımcılığın gizlenmeye çalışılması tokenizme örnek gösterilebilir (Kumkale, 2019, s. 1). 


\section{7. Çifte Açmaz}

Catalyst'e göre (2007); çifte açmaz (double bind) bir kişiden çelişkili talepler yapıldığında ortaya çıkan psikolojik bir çıkmaz; cezalandırıcı ve kaçınılmaz bir ikilemdir; böylece birey ne yaparsa yapsın yaptığı yanlış olarak yorumlanacaktır.

Her birey çifte açmazda kalma hissini kısacası ne yapılırsa yapılsın hiçbir hakka sahip olunamayacağı hissini az ya da çok yaşar. Bu durumu en çok örgüt yönetimindeki kadınların yaşadığı söylenebilir. Burada etkili olan faktör toplumsal cinsiyet kalıpyargılarıdır. Toplumsal cinsiyet kalıpyargıları, kadın liderler ve içinde çalıştıkları ve liderlik ettikleri örgütler için güçlü ama görünmez bir tehdit haline gelebilir. Bu kalıpyargılar kadınlar için çifte açmaz yaratarak; kadınları sınırlı ve elverişsiz tercihler yapmaya iter (Catalyst, 2007).

Kadın liderlerin sayısız ticari katkılarına rağmen, hala erkekler "Think Manager Think Male" düşüncesi ile lider olarak görülür. "Atipik liderler” olarak kadınlar genellikle liderlik normlarına aykırı olarak algılanır. Eril liderlik davranışlarına uymaya çalı̧̧malar beklenir (Catalyst, 2007). Otorite ve liderlik ile ilişkilendirilen özellikler aynı zamanda erkeklerle ilişkilendirilir. Dolayısıyla kadın için iki hedef çatışır; iyi bir lider olmakla ilgili beklentileri karşıladığı ölçüde, iyi bir kadın olmakla ilişkili olanları ihlal eder ya da iyi bir kadın olmakla ilgili beklentileri karşılıyorsa, bir liderin beklediğimiz özelliklerinden uzaklaşır. Çifte açmaz da bu noktada oluşur (Tannen, 2008, s. 127).

Catalyst'e göre (2007, s. 11) kadınların çifte açmaz durumları şu şekildedir;

- Kadın liderler cinsiyet kalıpyargıları ile tutarlı bir şekilde hareket ettiklerinde (iş ilişkilerine odaklanmak ve diğer insanların bakış açıları için endişelerini ifade etmek), yumuşak ve daha az yetkin liderler olarak görülmektedir. Bununla birlikte, kadınlar bu tür kalıpyargılardan farklı şekilde hareket ettiklerinde (iddialı, görev odaklı, hırslı), davranışları çok sert, hatta kadınsı olmayan davranışlar olarak değerlendirilir.

- Liderlik yeteneklerinin kanıtlanması söz konusu olduğunda, kadınlar erkeklerden daha yüksek standartlara tabidir. Aynı yetkinlik seviyesini göstermek için daha çok çalışmak zorundadırlar

- "Eril” liderlik tarzını benimseyen kadınlar daha olumsuz görülmektedir. Liderlik tarzlarından dolayı yetkin olarak görünseler de, kişiler arası becerileri "kadınsı" bir tarzı benimseyen kadınlardan daha olumsuz değerlendirilir. Bu nedenle, eril hareket eden kadın liderler için bu durumun çalışma ilişkileri ve sosyal ağlarla etkileşim açıcından olumsuz sonuçları vardır.

Kadın ve erkek çalışanları işe alım veya terfi için değerlendirirken, çalışanların yeteneklerini doğru bir şekilde değerlendirmelerini sağlamak için işletmelerin bu çifte açmazları dikkate alması önemlidir.

\subsection{Tiara Sendromu}

Sandberg (2013), kadınların genellikle iyi bir iş performansının doğal sonucu olarak terfi gibi iyi bir ödül getireceğine inandıkları için, ödül talebi konusunda daha isteksiz olduklarına dikkat çeker. Negotiating Women, Inc.'in kurucuları Carol Frohlinger ve Deborah Kolb bu durumu kadınların işlerini iyi yapmaya devam etmeleri halinde birilerinin onları fark edip başlarına bir "taç" koyacağını beklemesi olarak ifade edilen "Tiara 
Sendromu" olarak tanımlamaktadır. Mükemmel bir meritokraside, liyakata dayalı bir yönetimde, bu taçlandırmalar, ödüllendirmeler mümkündür (Sandberg, 2013); ancak, daha önce de bahsedildiği üzere çalışma yaşamı ayrımcı uygulamalar içermektedir.

Birçok çalışma Tiara sendromlu kadınların düşük benlik saygısına sahip olduklarını ve kariyer ilerlemeleri boyunca mücadele etmek zorunda olduklarını gösterir. Benlik saygısı oluşumunun beceriler, yetenekler ve sosyal ilişkiler hakkındaki kişisel inançlarla ilgili uzun bir süreç olduğu iddia edilir (Ambri vd., 2019, ss. 9-10). Eğitim ve farkındalıkla hem kadınların hem erkeklerin cinsiyetçi kalıpyargıları kırması sağlanarak bu durumun önüne geçilebilir.

\section{9. İmposter Sendromu}

Kendinden şüphe duyan yetenekli insanlar olgusunu tanımlayan kavram 'İmposter Sendromu'dur. Hem erkekler hem de kadınlar imposter sendromuna karşı hassas olsa da kadınlar bu sendromu daha yoğun deneyimleme eğiliminde olup, örgütsel katkılarına değer vermez (Vachon, 2014, s. 289).

Sandberg'e (2013) göre kadınlar sürekli kendini hafife almaktadır. Birden fazla endüstride yapılan çok sayıda çalışma, kadınların kendi performanslarını gerçekte olduğundan daha kötü değerlendirdiklerini, erkeklerin kendi performanslarını gerçekte olduğundan daha iyi değerlendirdiklerini göstermektedir. Özellikle kadınlar kendilerini başkalarının önünde ya da basmakalıp erkek egemen rollerinde değerlendirirken daha fazla hafife almaktadir.

Temelde birçok kadının sosyalleşme sürecinde öğrenip içselleştirdiği toplumsal cinsiyet kalıpyargıları, imposter sendromu semptomlarına (kendini düşük değerleme ve hafife alma) neden olur. Kalıpyargılar, saldırgan ve zorlayıcı kadınların toplum tarafından kabul edilebilir davranışlarla ilgili yazılı olmayan kuralları ihlal ettiğini öğretmektedir. Erkekler sürekli olarak hırslı, güçlü ve başarılı oldukları için alkışlanırken aynı özellikleri sergileyen kadınlar genellikle sosyal bir ceza öderler; kadının başarılı olmasının bir bedeli vardır. Örneğin bir erkek başarılı olduğunda, hem erkekler hem de kadınlar tarafından sevilirken; bir kadın başarılı olduğunda, her iki cinsiyetten insanlar onu daha az sever (Sandberg, 2013; Vachon, 2014, s. 290). Erkekler için profesyonel başarı, yolun her adımında olumlu pekiştirmelerle gelirken; kadınlar başarıları için tanınsalar bile, çoğu zaman elverişsiz sayılırlar (Sandberg, 2013). Çoğu liderlik pozisyonu erkeklerin elinde olduğu için kadınlar o pozisyonlara ulaşmayı beklemez ve pozisyon için çabalamaz. Aynı şey ücretler için de geçerlidir. Erkekler genellikle kadınlardan daha fazla kazanır, bu yüzden insanlar kadınların daha az kazanmasını bekler ki gerçekte de daha az kazanırlar (Vachon, 2014, s. 290). Sonuç olarak bu kalıpyargıların çoğu kadınlara başkalarına bağımlı olmayı ve geri planda kalmayı öğretmekte ve başkalarının kendilerinden daha çok katkıda bulunacağına ve daha değerli olduğuna inanmalarına neden olmaktadır (Sandberg, 2013).

Yapılan birçok çalışma imposter sendromunun düşük özgüven ve benlik saygısı ile ilgili olduğunu ortaya koymuştur (Ambri vd, 2019, s. 10). Örneğin erkekler başarısını kendi doğuştan gelen niteliklerine ve becerilerine bağlarken; kadınlar başarısını daha çok şans ya da başkalarından yardım alma gibi dış etkenlere 
bağlama eğilimindedir. Erkekler ve kadınlar başarısızlığı açıklama konusunda da farklılık gösterir. Bir erkek başarısız olduğunda, yeterince çalışmadığı ya da konunun ilgisini çekmediği gibi faktörlere işaret ederken; bir kadın başarısız olduğunda, bunun doğal bir yetenek eksikliğinden kaynaklandığına inanma eğilimindedir. Ayrıca erkekler ve kadınlar olumsuz geri bildirim durumlarında da farklı tepkiler verir ve kadının kendine güveni, kendine saygısı erkeklere nazaran çok daha fazla azalır. Başarısızlığın kadınlar tarafından içselleştirilmesi ve kadınlarda doğurduğu güvensizlik gelecekteki performansa zarar vereceği için uzun vadeli ciddi sonuçlar doğurabilir (Sandberg, 2013).

\subsection{Cam Labirent}

Profesyonel meslek yaşamında kadınların sorunlarına yönelik bir diğer metafor cam labirenttir. Labirent; bir hedefe doğru karmaşık bir yolculuk fikrini aktarır. Bir labirentten geçiş basit veya doğrudan değildir; kalııılık, farkındalık ve ileriye dönük analiz gerektirir. Cam labirent kavramını çalışma yaşamında kavramsallaştıran Eagly ve Carli’ye göre (2007) üst düzey liderlik isteyen kadınlar için labirentteki yollar hem beklenmedik hem de beklenen bükülme ve dönüşlerle doludur. Kadın liderlerin labirentlerle karşılaşmasının erkeklere fayda sağlayan ve kadınları cezalandırılan kalıpyargılarla başladığı söylenebilir. Hala kadınların liderlik özellikleri ve iş-aile sorumluluklarının dengelenmesinin zorluğu ile ilgili önyargılar kadınların önünde engeldir. Birçok kadın için labirentteki en keskin dönüşler, aile sorumluluklarının baskısı altında olanlardır. Ancak engellerle dolu tüm labirentler merkeze uygun bir rotaya sahip oldukları için hedeflere ulaşmak mümkündür (Eagly ve Carli, 2007).

\subsection{Cam Duvar}

Kadınların üst düzey yönetim pozisyonuna gelmesi ve kariyer ilerlemesi yönündeki bir diğer görünmez engel de cam duvardır. Cam duvarlar örgütlerde kadınların yükselebilmesi için deneyimlemesi gereken yönetim pozisyonuna yükselme sağlayan ve işin öğrenildiği bölüme geçişe olanak veren yatay mobilizasyonu engeller ve kadını stratejik olarak önemli olmayan ve geleneksel olarak kadın işi olarak görülen işlere ve pozisyonlara mahkum eder (Weidenfeller, 2012; Sabharwal, 2013, s. 399; Yıldız, 2017, s. 130) .

\section{Sonuç ve Değerlendirme}

Tarihsel süreçte kadınlar birçok toplumda erkeklerin gölgesinde kalmıştır. Günümüzde kadın-erkek eşitsizliği belli başlı politika ve uygulamalarla azaltılmaya çalışılsa da, toplumsal cinsiyet kalıpyargılarının hala erkekler lehine olduğu görülmektedir. Bu durum/erkek egemen ideoloji toplumsal yaşamda firsat eşitsizliği yaratmakta; özellikle çalışma yaşamında kadınlar aleyhine durumlara neden olmaktadır. Çalışma yaşamı açısından bakıldığında bu kalıpyargılar sonucu oluşan cinsiyete dayalı ayrımcılık açıkça görülmektedir. Bu ayrımcılık kadınlar için hem daha düşük ücret ve güvencesiz çalışma hem de sınırlı kariyer ilerleme firsatı anlamına gelmektedir.

Kadınların yaşadığı ayrımcılık cam tavan, cam asansör, cam uçurum, yapışkan zemin, sızdıran boru, kraliçe arı gibi metaforlarla anlatılmaya çalışılmaktadır. Bütün bu kavramlarda temel nokta toplumsal cinsiyet 
kalıpyargıları sonucu oluşan ayrımeı tutum ve davranışlardır. Bu ayrımcı tutum ve davranışlar kadınları çalışma yaşamında dezavantajlı duruma sokmakta, kadınların hak ettikleri pozisyona gelmelerini ve erkeklerle eşit konumda olmalarını engellemektedir. Çalışma yaşamındaki kadın cam tavanı aşıp yönetim kademesine yükselse dahi; genellikle güvencesiz ve riskli durumlarda kadına verilen yönetim görevinde başarısız olma olasılığı ile karşı karşıya kalır. Ya da yönetim kademesine yükselmiş bir kadın pozisyonunu korumak için cinsiyetçi kalıpyargıları sürdüren davranışlar sergileyebilir ve hemcinslerine karşı olumsuz tutum takınabilir. Kadın iş - aile -yaşam dengesini sağlamaya çalışırken çalışma yaşamında çekilebilir ya da hemcinsinin egemen olduğu mesleklerde bile yükselme şansı bulamayabilir. Bu durumlar kadınlarda düşük benlik saygısına, kendini düşük değerlemeye, psikosomatik sorunlara, tükenmişlik sendromuna vb yol açarak hem iş hem yaşam tatminini olumsuz yönde etkileyebilir.

Kalıpyargılar sonucu oluşan ayrımcı ve eşitsiz tutum, çalışma yaşamının tüm aşamalarında şeffaflık ve cinsiyet duyarlılığının benimsenmesi, kurumsallaştırılmış ilkeler oluşturulması ve dolayısıyla toplumsal cinsiyet eşitliği farkındalığının sağlanması ile engellenebilir. Her ne kadar bazı mesleklerde ayrımcı uygulamaları gizleyebilmek adına sembolik olarak kadınlara yer verilse de; gerçek bir eşitliğe ulaşmak için, işgücü piyasasının ötesine geçen ve toplumsal cinsiyet kalıpyargılarını kıran daha kapsamlı değişiklikler gerekmektedir.

\section{Kaynakça}

Ambri, S., Tahir, L.M. ve Alias, R. A. (2019, December). An overview of glass ceiling, tiara, imposter, and queen bee barrier syndromes on women in the upper echelons. Asian Social Science, (15)1, 8-13. doi: $10.5539 /$ ass.v15n1p8

Beauvoir, S. D. (2019). İkinci cinsiyet olgular ve efsaneler. (G.Savran, .çev). İstanbul: KoçKam.

Bennett, C. (2011). Beyond the leaky pipeline: consolidating understanding and incorporating new research about women's science careers in the UK. Brussels Economic Review-Cahiers Economiques De Bruxelles, (54)2-3, $149-176$.

Bora, A. (2018). Kadınların sınıfi ücretli ev emeği ve kadın öznelliğin inşası. İstanbul: İletişim Yayınları.

Casini, A. (2016). Glass ceiling and glass elevator. The Wiley Blackwell encyclopedia of gender and sexuality studies (1-2), Chicester: Wiley-Blackwell.

Cotter, D., Hermsen, J., Ovadia, S. ve Vanneman, R. (2001). The glass ceiling effect. Social Forces, 80(2), 655-681. doi: 10.1353/sof.2001.0091

Derks, B. (2017). Queen bee syndrome. S. G. Rogelberg (Ed.). The SAGE encyclopedia of industrial and organizational psychology. Thousand Oaks. California: SAGE Publications, 2nd edition.

Derks, B., Ellemers, N., Laar, C. ve Groot, K. (2011). Do sexist organizational cultures create the queen bee?. British Journal of Social Psychology, 50, 519-535. doi: 10.1348/014466610X525280

Derks, B., Laar, C. ve Ellemers, N. (2016). The queen bee phenomenon: why women leaders distance themselves from junior women. The Leadership Quarterly, 27, 456-469. doi: https://doi.org/10.1016/j.leaqua.2015.12.007

Dill, J. Price-Glynn, K., Rakovski, C. (2016). Does the "glass escalator" compensate for the devaluation of care work occupations? the careers of men in low - and middle - skill health care jobs. Gender\&Society, 30(2), 334-360. doi: https://doi.org/10.1177\%2F0891243215624656

Dökmen, Z. (2010). Toplumsal cinsiyet: sosyal psikolojik açıklamalar. İstanbul: Remzi Kitabevi

Dreher, G. F. (2003). Breaking the glass ceiling: the effects of sex ratios and work-life programs on female leadership at the top. Human Relations, 56(5), 541-562. doi: http://dx.doi.org/10.1177/0018726703056005002 
Durmaz, Ş. (2016). İşü̈cü piyasasında kadınlar ve karşılaştıkları engeller. Ahi Evran Üniversitesi Sosyal Bilimler Enstitüsü Dergisi (AEÜSBED), 2(3), 37-60. $\quad$ URL: https://dergipark.org.tr/tr/pub/aeusbed/issue/26794/282028

Er, O., Adıgüzel, O. (2015). Cam tavan gölgesindeki kraliçe arılar: kadınların kariyer ilerlemelerinde karşılaş̧ıkları engeller ve etkili liderlik. Recep Tayyip Erdoğan Üniversitesi Sosyal Bilimler Dergisi, 1(2), 163175. URL: https://dergipark.org.tr/tr/pub/rteusbe/issue/26018/274028

European Commission. (1998). A Hundred Words For Equality - A Glossary Of Terms On Equality Between Women And Men, Luxembourg: Office for Official Publications of the European Communities.

EIGE, European Institute For Gender Equality. Gender Equality Glossary and Thesaurus. Erişim: 5 Nisan 2020. https://eige.europa.eu/search?t=sticky+floor\&op=Search

Haslam, S. A., Ryan, M. K. (2008). The road to the glass cliff: differences in the perceived suitability of men and women for leadership positions in succeeding and failing organizations. The Leadership Quarterly, 19(5), 530-546. doi: https://doi.org/10.1016/j.leaqua.2008.07.011

Kiausiene, I., Streimikiene, D. (2011). On gender stereotyping and employment assimetries. Economics\&Sociology, 4(2), 84-97. doi: http://dx.doi.org/10.14254/2071-789X.2011/4-2/8

Korkmaz, A., Başer, M. (2019). Toplumsal Cinsiyet Rolleri Bağlamında Ataerkillik ve İktidar İlişkileri. STED, 28 (1), 71 - 75. doi: $10.17942 /$ sted.507660

Kumkale, İ. (2019). Tokenizm ve token kadınlar. İ. Kumkale. (Ed.), Kadının İş Yaşamı ve Etik, 1- 5. Ankara: Nobel Yayincilik.

Macarie, F., Moldovan, O. (2012). Gender discrimination in management: theoretical and empirical perspectives. Transylvanian Review of Administrative Sciences, 35(E), 153-172. URL: https://ssrn.com/abstract=2098052

Mavin, S. (2008). Queen bees, wannabees and afraid to bees: no more 'best enemies' for women in management?. British Journal of Management, 19, 75-84. doi: https://doi.org/10.1111/j.1467$\underline{8551.2008 .00573 . \mathrm{x}}$

OECD, Organisation for Economic Co-operation and Development. Gender differences in employment $\begin{array}{lllll}\text { outcomes. } & \text { Erişim: } & 5 & \text { Nisan } & 2020 .\end{array}$ https://www.oecd.org/els/soc/LMF_1_6_Gender_differences_in_employment_out comes.pdf

Özçatal, E. Ö. (2011). Ataerkillik, Toplumsal Cinsiyet ve Kadının Çalışma Yaşamına Katılımı. Çankırı Karatekin Üniversitesi İktisadi ve İdari Bilimler Fakültesi Dergisi, 1 (1), 21 - 39. URL: https://dergipark.org.tr/tr/download/article-file/382051

Pascall, A. N. (2012). Engendering Technology Empowering Women.Tilburg: TiCC, Ph.D. Series 23.

Price-Glynn, K., Rakovski, C. (2012). Who rides the glass escalator? gender, race and nationality in the national nursing assistant study. Work, Employment And Society, 26(5), 699-715. doi: https://doi.org/10.1177\%2F0950017012451634

Rajenderan, M., Zawawi, D. (2019). Leaky pipeline syndrome in information and communication technology (1ct) 1ndustry of Malaysia: a conceptual study on female career barriers and retention management. International Journal of Academic Research in Business and Social Sciences, 9(2), 1158-1174. doi: http://dx.doi.org/10.6007/IJARBSS/v9-i2/5672

Ryan, M. K., Haslam, S. A. ve Postmes, T. (2007). Reactions to the glass cliff: gender differences in the explanations for the precariousness of women's leadership positions. Journal Of Organizational Change Management, 20(2), 182 -197. doi: http://dx.doi.org/10.1108/09534810710724748

Ryan, M. K., Haslam, S. A., Hersby, M. D. ve Bongiorno, R. (2011). Think crisis - think female: the glass cliff and contextual variation in the think manager - think male stereotype. Journal of Applied Psychology, 96(3), 470 - 484. doi: http://dx.doi.org/10.1037/a0022133

Sabharwal, M. (2013). From glass ceiling to glass cliff: women in senior executive service. Journal of Public Administration Research and Theory, 25(2), 399-426. doi: http://dx.doi.org/10.1093/jopart/mut030

Sandberg, S. (2013). Lean in: women, work, and the will to lead. Canada: LeanIn Foundation

Schein, V. E., Mueller, R., Lituchy, T. ve Liu, J. (1996). Think manager - think male: a global phenomenon?. Journal of Organizational Behavior, 17(1), 33-41. doi: https://doi.org/10.1002/(SICI)10991379(199601)17:1\%3C33::AID-JOB778\%3E3.0.CO;2-F 
Smith, R. A. (2012). Money, benefits, and power: a test of the glass ceiling and glass escalator hypotheses. The Annals of the American Academy of Political and Social Science, 639(1), 149-172. doi: https://doi.org/10.1177\%2F0002716211422038

Sobczak, A. (2018). The queen bee syndrome. the paradox of women discrimination on the labour market. Journal of Gender and Power, 9(1), 51-61. doi: https://doi.org/10.14746/jgp.2018.9.005

Tannen, D. (2008). The double bind. S. Morrison (Ed.), Thirty ways of looking at Hillary: reflections by women writers, New York: HarperCollins

Taş, G. (2016). Feminizm üzerine genel bir değerlendirme: kavramsal analizi, tarihsel süreçleri ve dönüşümleri. Akademik Hassasiyetler, 3(5), 163-175. URL: https://dergipark.org.tr/tr/pub/akademikhassasiyetler/issue/27268/287075

Vachon, J. C. (2014). Tiaras, Queen Bees, Imposters and the Board Room: Lean In \& Women in Corporate Governance. Journal of Business \&Technology Law, 9(2), 279-292.

Weidenfeller, N. K. "Breaking Through The Glass Wall: The Experience Of Being A Woman Enterprise Leader". Human Resource Development International 15/3 (2012), 365-374. URL: https://digitalcommons.law.umaryland.edu/jbtl/vol9/iss2/6

Williams, C. L. (1992). The glass escalator: hidden advantages for men in the "female" professions. Social Problems, 39(3), 253-267. doi: https://psycnet.apa.org/doi/10.1525/sp.1992.39.3.03x0034h

Williams, C. L. (2013). The glass escalator, revisited: gender inequality in neoliberal times, sws feminist lecturer. Gender \& Society, 27(5), 609-629. doi: https://doi.org/10.1177\%2F0891243213490232

Wingfield, A. H. (2009). Racializing the glass escalator: reconsidering men's experiences with women's work. Gender \& Society, 23(1), 5-26. doi: https://doi.org/10.1177\%2F0891243208323054

Wirth, L. (2001). Women in management: closer to breaking through the glass ceiling?,Geneva: ILO Publications

Yıldız, S., Alhas, F., Sakal, Ö. ve Yıldız, H. (2016). Cam uçurum: kadın yöneticiler cam tavanı ne zaman aşar?. Ankara Üniversitesi SBF Dergisi, 71(4), 1119 - 1146. doi: https://doi.org/10.1501/SBFder 0000002425

Yıldız, S. (2017, Haziran). Toplumsal cinsiyetin şirketlere yansımasında ortaya çıkan ayrımcılık kavramlarının ardılları üzerine bir model önerisi. Eskişehir Osmangazi Üniversitesi Sosyal Bilimler Dergisi, 18(1), 121-138. doi: https://doi.org/10.17494/ogusbd.330753

Zel, U. (2002). İş arenasında kadın yöneticilerin algılanması ve kraliçe arı sendromu. Amme İdaresi Dergisi, 35(2), 39-48. Doi:

Zimmer, L. (1988). Tokenism and women in the workplace: the limits of gender-neutral theory. Social Problems, 35(1), 64-77. doi: https://doi.org/10.2307/800667 